\title{
Influence of Recycled Aggregate Composites on the Factor of Safety of Earthen Structures
}

\author{
Md. Zakaria Hossain \\ Department of Environmental Science and Technology, Mie University, Mie, Japan \\ Email: zakaria@bio.mie-u.ac.jp
}

Received April 19, 2013; revised May 23, 2013; accepted June 22, 2013

Copyright (C) $2013 \mathrm{Md}$. Zakaria Hossain. This is an open access article distributed under the Creative Commons Attribution License, which permits unrestricted use, distribution, and reproduction in any medium, provided the original work is properly cited.

\begin{abstract}
In this study, six composite reinforcements such as cement composite made of Abandoned Cell Husks (ASH), Stones, Wood chips, Concrete and Bricks have been used along with control specimen. It is known that the material used in earth reinforcement applications must be safe against tension failure and adhesion failure for its effective utilization in the field and reliable design of earth structures. Single type of material can provide limited reinforcement capability in reinforced earth structures due to its low frictional resistance and poor cohesion. For an optimal response, therefore, composite reinforcement, that fulfils both the requirements such as possess adequate tensile strength and adequate frictional resistance, is getting considerable attention. Slope stability analyses containing six types of reinforcement have been performed. Stability of the slope has been quantified using minimum factor of safety corresponding to critical slip surface. It was observed that the composite reinforcement whose surface treated by brick aggregate enhanced the factor of safety significantly. The paper also depicted the design aids of reinforced slope in terms of embedding lengths and spacing of reinforcements.
\end{abstract}

Keywords: Earthen Structures; Stability Factor; Composite Reinforcement; Recycled Aggregate

\section{Introduction}

The embankments, dams, foundations, abutments and all earth fill structures must be stable under all static and dynamic loadings during construction and on-service [1]. Collapse in earth fill embankments occurs at the critical slip surface when the factor of safety $\left(F_{s}\right)$ decreases due to weathering, erosion, seepage, changes of surface and subsurface water, earthquake and many other natural calamities [2-8]. In order to obtain a necessary factor of safety for a given slope, it must be reinforced to improve the stability above the safety level. There are various earth reinforcing materials worldwide. Among them, the geosynthetic or geogrid are conventional reinforcements that are commonly used for earth reinforcement applications. It is evident that the conventional reinforcements, used for reinforcing earth fill structure, contain only one type of material such as geogrid, geosynthetic or wire mesh etc. The material used in earth reinforcement applications must be safe against tension failure and adhesion failure for its effective utilization in thefield and safe design of earth structures [9-11]. For a given situation, single type of material can provide limited reinforcement capability in reinforced earth structures due to its low frictional resistance and poor cohesion. For an optimal response, therefore, different types of reinforcement that fulfils both the requirements such as possess adequate tensile strength and adequate frictional resistance, is getting considerable attention lately $[12,13]$.

Stability analysis is usually performed to find out the factor of safety of the earth fill structures [14-18]. Referring to Figure 1, the composite reinforcement provides resisting force thereby increases the factor of safety of the fill embankments. In this paper, slope stability analyses containing six types of composite reinforcement have been performed. Thin reinforced-mortar composite consisting of evenly distributed fine mesh as the reinforcement and cement-sand mortar as the matrix showed enhanced performance because of its synergetic action of mesh with mortar and mortar with soil [19-23]. Considering the facts given above, slope stability analyses for reinforced embankments containing various types of composite reinforcements have been conducted using simplified method. Six composite materials were used Surface treatment for five types of composite specimens were made by using Abandoned Cell Husks (ASH), Stones, Wood chips, Concrete and Bricks. The control 
specimen was prepared without any surface treatment. The analyses were performed in such a way so that the most critical slip surface which showed Minimum Factor of Safety $\left(F_{s} \min \right)$ was identified based on random search technique. The factors of safety for various slope having different slope inclination $\left(30^{\circ}, 45^{\circ}\right.$ and $\left.60^{\circ}\right)$ and different angle of internal have been reported in tabular and graphical form as a ready reference for design of reinforced slope containing composite reinforcement. Relationships between the slope inclination and number of layers of composite reinforcements and layer spacing are given as a ready reference to ease in the design of reinforced embankments.

\section{Materials and Methods}

The conventional soil reinforcement materials are shown in Figures 2 and 3. The composite reinforcements used in this study are shown in Figures 4-9.

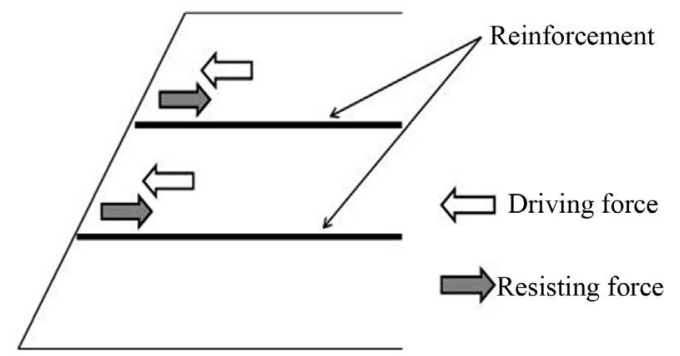

Figure 1. Placement of composite reinforcement for slope stability.

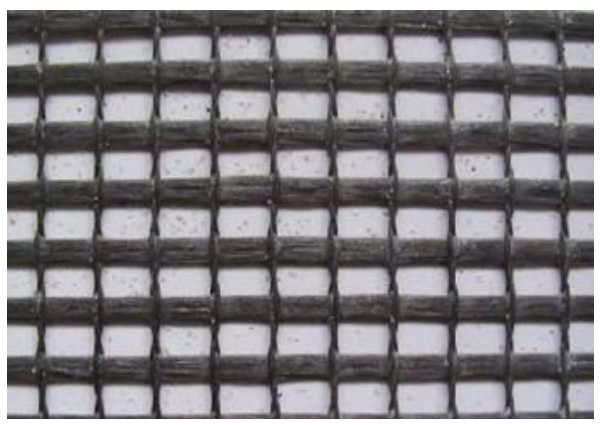

Figure 2. Geogrid mesh (basalt mesh).

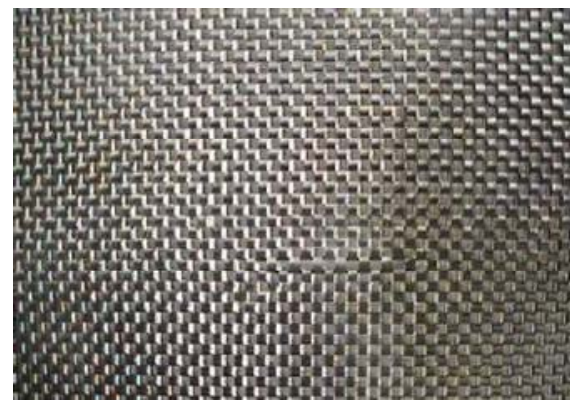

Figure 3. Geosynthetics (basalt material).

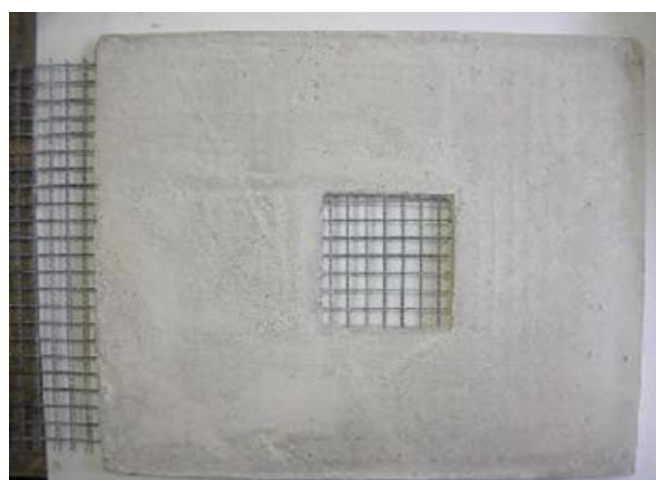

Figure 4. Control specimen $(43 \times 35 \times 1.5 \mathrm{com})$.

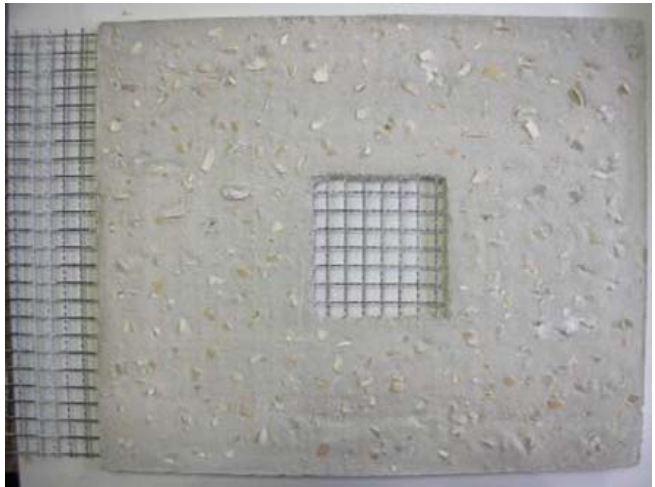

Figure 5. ASH (Abandoned shell husk).

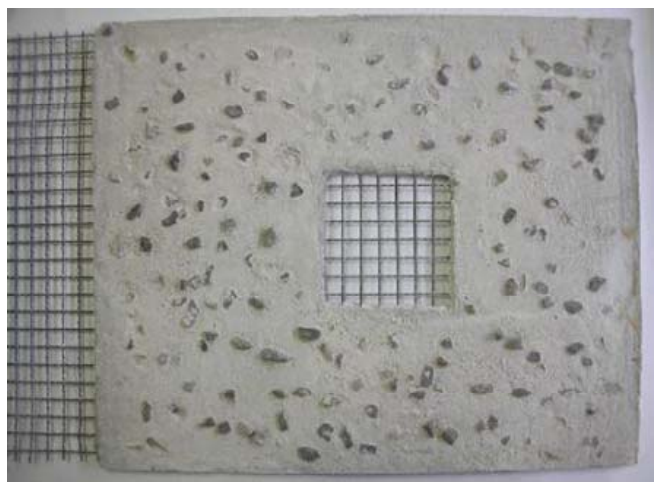

Figure 6. Stone cement composite.

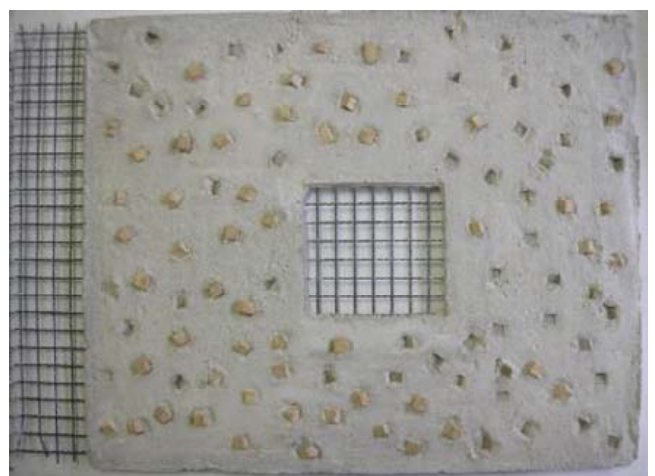

Figure 7. Wood cement composite. 


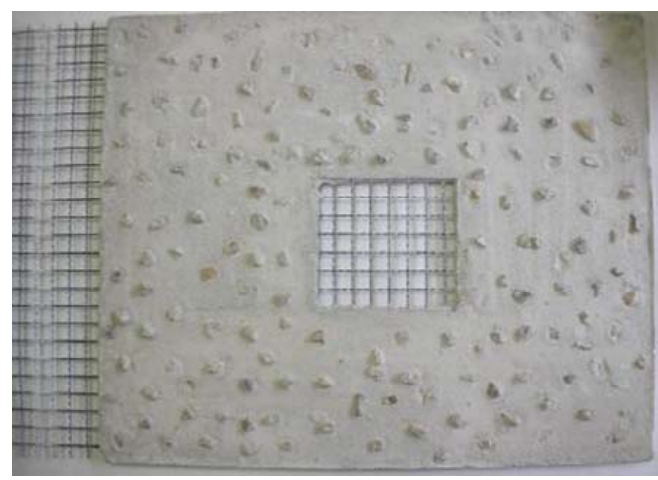

Figure 8. Concrete cement composite.

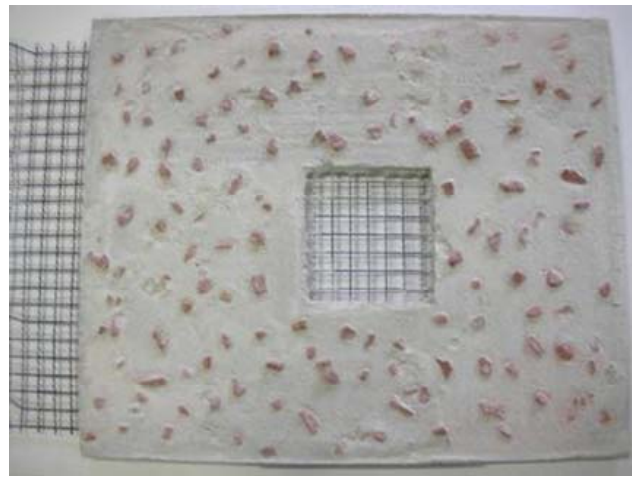

Figure 9. Brick cement composite.

\section{Determination of Shear Resistances of Composite Reinforcements}

Details of soils-reinforcements interaction studies can be found elsewhere [21-23]. The apparatus used in this study is shown in Figure $\mathbf{1 0}$ which is capable of performing direct shear tests and pullout tests. The panels were clamped in the box in such a way that the embedded length of the panel is $38.0 \mathrm{~cm}$ in the loading direction and $31.6 \mathrm{~cm}$ in the transverse direction. After embedding the composite reinforcement on the lower box; the upper part was set on the panel, and then the sand was rained in the upper box. The tests were carried out in such a way that the panel along with lower box was pushed out from the san in the upper box. The shear speed was $1 \mathrm{~mm}$ per minute. However, it can be fixed at any slower/faster speed. The shear force and the displacements were measured at the lower box by means of LVDTs and the data were recorded in a computer system directly. Results obtained from the experiment are given in Table 1.

\section{Slope Stability Analyses with and without Reinforcements}

A brief description is given in this paper and detailed procedure can be found elsewhere (Hossain et al., 2012). External and internal forces acting on the slope and a slice are shown in Figure 11. Here, $E_{a}$ and $T_{a}$ are horizontal and vertical external driving forces acting at upper face of the slope. The external horizontal and vertical resisting forces $E_{b}$ and $T_{b}$ are acting at the toe of the slope. The other vertical and horizontal forces caused by surcharge due to external loadings and body forces are shown by $P$ and $Q$, respectively.

The horizontal and vertical boundary forces $E$ and $T$ or $t$ are acting at a height ht from the base of the slice. The differences of forces for slice (width $\Delta X$ ) are $\Delta E$ and $\Delta T$ and the difference of forces for external loading are $\Delta Q$ and $\Delta P$. The parameter $U$ is the water force acting upward at the base of the slice. The $\sigma$ and $\tau$ are normal and shear stresses acting beneath the slice.

The factor of safely is calculated based on the parameters $A$ and $B$, resisting and driving forces, respectively and is given the following equation:

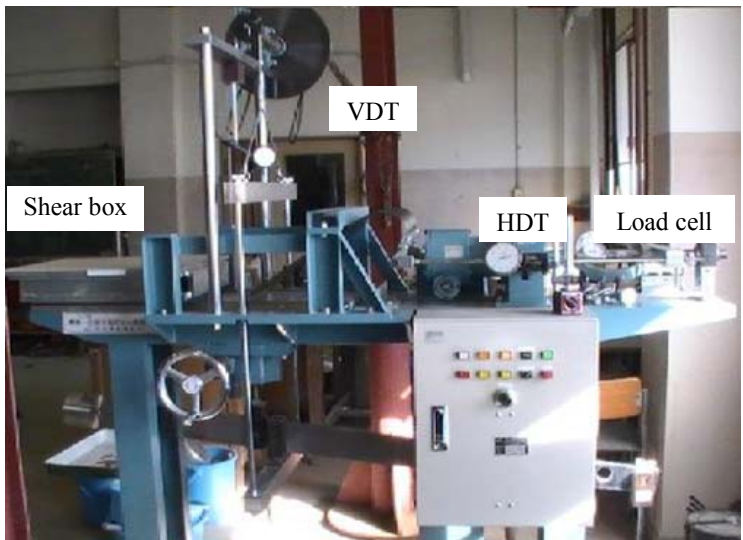

Figure 10. Apparatus used for testing shear and pullout resistances of composite reinforcements.

Table 1. Surface roughness of reinforcements and resistance coefficient.

\begin{tabular}{ccc}
\hline Specimen & Roughness, Degree & $\begin{array}{c}\text { Resistance } \\
\text { Coefficient }\end{array}$ \\
\hline Toyoura Sand & 30.00 & 1.00 \\
Geosynthetic (Basalt Cloth) & 16.00 & 0.53 \\
Geogrid (Basalt Mesh) & 27.00 & 0.90 \\
$\begin{array}{c}\text { Composite Reinforcement } \\
\text { (Control) }\end{array}$ & 32.25 & 1.14 \\
$\begin{array}{c}\text { Composite with Abandoned } \\
\text { Cell Husks (ASH) } \\
\text { Composite with Stone } \\
\text { Composite with Wood Chips } \\
\text { Composite with } \\
\text { Recycled Concrete } \\
\text { Composite with Brick Aggregate }\end{array}$ & 35.50 & 1.19 \\
\hline
\end{tabular}




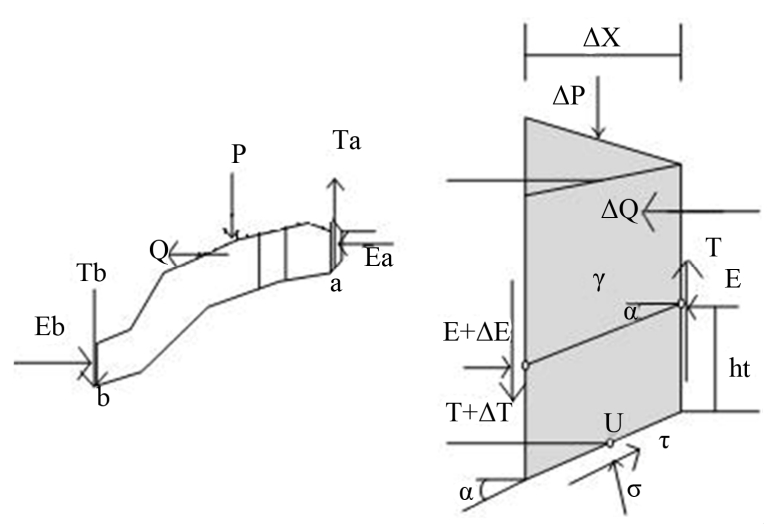

Figure 11. Forces acting on a slope and a slice.

$$
F_{s}=\frac{\sum A}{E_{a}-E_{b}+\sum B}
$$

where,

The apparent resisting moment $A$ is the function of cohesion, frictional resistance and resisting external forces acting on the slice and is given by:

$$
A=\frac{A^{\prime}}{n_{\alpha}}
$$

where:

$$
A^{\prime}=[c+(p+t-u) \tan \varphi] \Delta x
$$

The $n_{\alpha}$ is a parameter given by frictional resistance, inclination of slip surface along with factor of safety which is given by the following equation:

$$
n_{\alpha}=\frac{1+\left(1 / F_{s}\right) \tan \varphi \tan \alpha}{1+\tan ^{2} \alpha}
$$

And the driving moment $B$ is the function of external force, water force and angle of slip surface which is given by the following equation:

$$
B=\Delta Q+(p+t) \Delta x \tan \alpha
$$

All the above equations are for fill embankments without any reinforcement. Considering the facts for improving the factor of safety of fill embankments, the following equations have been proposed.

$$
\begin{array}{r}
A^{\prime}=[c+(p+t-u) \beta \tan \varphi] \Delta x \\
n_{\alpha}=\frac{1+\left(1 / F_{s}\right) \beta \tan \varphi \tan \alpha}{1+\tan ^{2} \alpha}
\end{array}
$$

The vertical component of load/weight of slope is defined by $\mathrm{p}$ and the average pore water pressure is defined by $u$. The other parameters in the above equations are conventional such as cohesion and angle of internal friction are defined by $c$ and $\varphi$. The parameter $\beta$ is defined as coefficient of frictional resistances which is employed in the proposed equations due to the additional resisting forces come from the embedment of composite reinforcements.

The analyses were performed using the programming in Microsoft excels spreadsheet as given in Figure 12. The program starts with an initial slip surface and calculates the $F_{s}$ for it. It then performed repeated analyses for several trial slip surfaces in order to search the critical slip surface and obtained final slip surface of which the $F_{s}$ is minimum.

The following steps were followed to obtain the complete convergence of the factor of safety values.

Step 1 Input date for a given slope such as soil parameters, slope properties, boundary conditions, external and internal forces etc. (marked by red color).

Step 2 Calculating $n_{\alpha}$, A and $F_{s}$ repeatedly until the convergence of $F_{s}$ become 1.5 (marked by green color).

Step 3 Substituting the $F_{s}$ obtained in Step 2 in equation $n_{\alpha}$ and calculating the $F_{s}$ again considering the boundary forces of the slice (marked by blue color).

Step 4 Calculating the $E$ and $T$ from Step 3 and then calculating the final $F_{S}$ from this (marked by blue color in Step 4).

\section{Results and Discussion}

The minimum factors of safety $\left(F_{s} \min \right)$ along with coefficient of frictional resistance $(\beta)$ calculated for the unreinforced and reinforced embankments with different

\begin{tabular}{|c|c|c|c|}
\hline & \multicolumn{3}{|c|}{ Minimum factor of safety } \\
\hline & $\alpha=130^{\circ}$ & $A=45^{\circ}$ & $A=60^{\circ}$ \\
\hline Unreinforced slope & 1.11 & 0.084 & 0.056 \\
\hline $\begin{array}{l}\text { Reinforced slope } \\
\text { with geosynthetics }\end{array}$ & 1.12 & 0.55 & 0.44 \\
\hline Reinforced slope with geogrid & 1.18 & 0.85 & 0.62 \\
\hline $\begin{array}{l}\text { Reinforced slope with } \\
\text { control composite }\end{array}$ & 1.35 & 0.95 & 0.64 \\
\hline $\begin{array}{l}\text { Reinforced slope with } \\
\text { ASH composite }\end{array}$ & 1.40 & 1.00 & 0.66 \\
\hline $\begin{array}{l}\text { Reinforced slope with } \\
\text { stone composite }\end{array}$ & 1.48 & 1.06 & 0.70 \\
\hline $\begin{array}{l}\text { Reinforced slope with } \\
\text { wood composite }\end{array}$ & 1.56 & 1.11 & 0.73 \\
\hline $\begin{array}{l}\text { Reinforced slope with } \\
\text { concrete composite }\end{array}$ & 1.62 & 1.16 & 0.76 \\
\hline $\begin{array}{l}\text { Reinforced slope with } \\
\text { brick composite }\end{array}$ & 1.68 & 1.20 & 0.79 \\
\hline
\end{tabular}
slope inclinations $(\alpha)$ are given in Table 2 .

It is observed that the $F_{s}$ min for unreinforced embankments for slope inclination of $30^{\circ}, 45^{\circ}$ and $60^{\circ}$ are $1.19,0.84$ and 0.56 respectively indicating that the $F_{s} \min$

Table 2. Factor of safety values for unreinforced embankments with $\varphi=40^{\circ}$. 


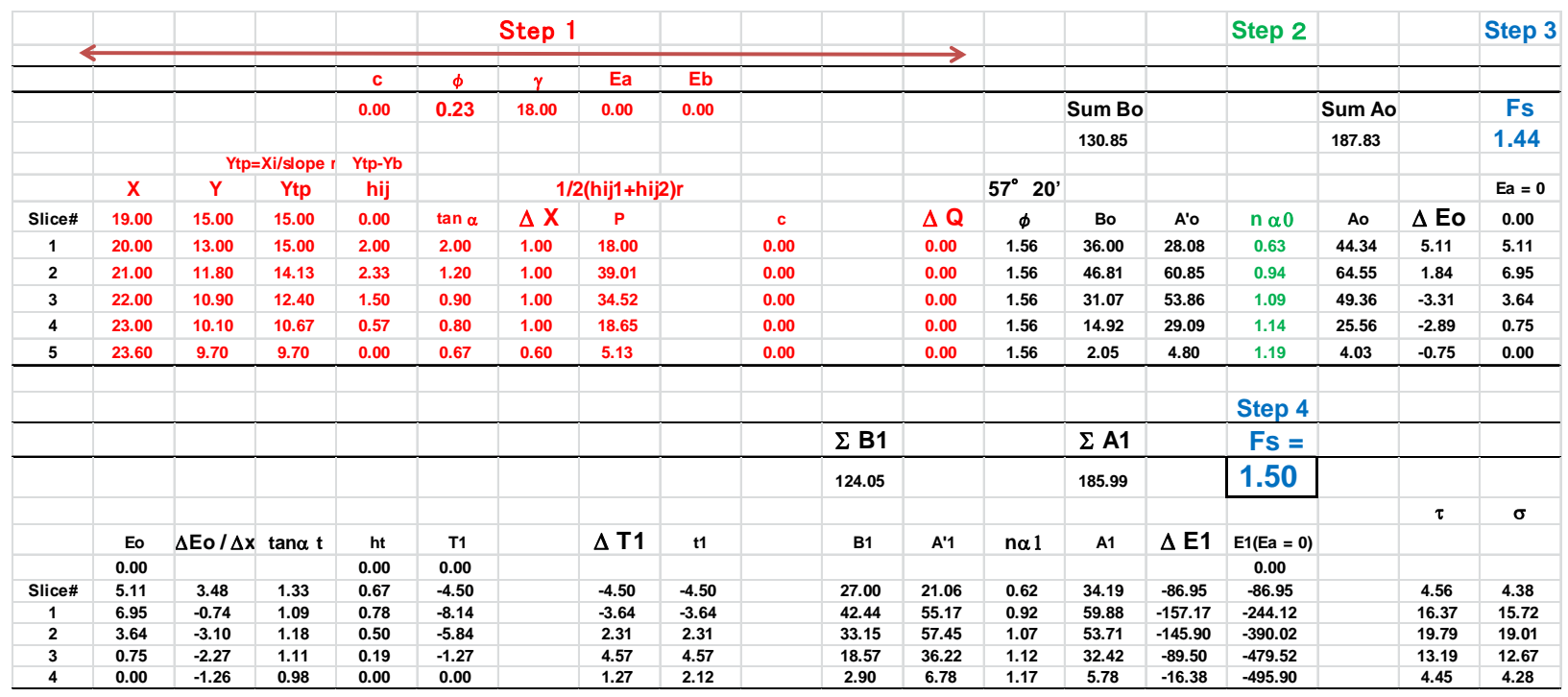

Figure 12. Factor of safety obtained by slope stability analyses.

decreased with the increase of slope inclination. This is obvious due to the driving forces for unreinforced slope with the increase of slope inclination. For improving the stability of the slope, composite reinforcements were impregnated. The factor of safety values were increased with the increase of composite reinforcements. This is expected because the reinforcement embedded inside the soil resulted more stress-transfer ability of the composites thereby increased the resisting forces. It is also noticed that the brick treated cement composites exhibits the maximum enhancement in the factor of safety values. This is apparent owing to the synergy between the two materials in the hybrids such as synergetic action of mesh with mortar and brick treated mortar with soil. The time effects of different reinforcements have not been studies in this present research because the data noted in this paper were obtained by short term experiment. It is recommended to perform long term durability tests of different reinforcements for better comparison.

For convenient design of reinforced fill embankments, relationships between factor of safety and inclination of slope along with required length of reinforcement to be embedded and spacing between the reinforcement are shown in Figure 13. Form this figure one can easily design stable embankments by selecting necessary reinforcements, embedding length and spacing. As can be seen, the composite reinforcement surface treated with wood, concrete and brick provides factor of safety 1.5 or more. In this case, the length of the embedment should be more than $1.7 \mathrm{~m}$ and spacing should be $1.0 \mathrm{~m}$. A closer inspection of the plotted results revealed that the increment trend of the safety factor containing composite reinforcements are somewhat different from the safety factor that were observed in case of unreinforced or conventional reinforcements embankments thereby, further

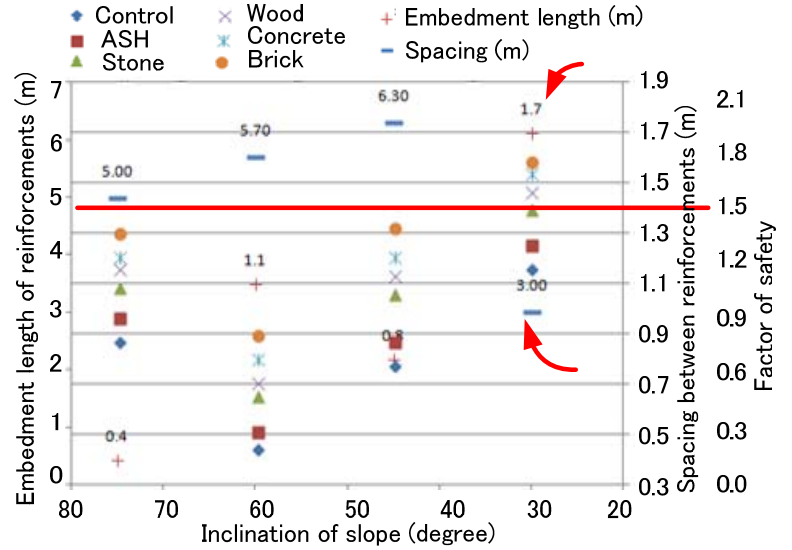

Figure 13. Length and spacing of reinforcements.

optimization attempts using surface treated composite reinforcement are obviously warranted.

\section{Conclusion}

In this research work, frictional resistance and the effectiveness of composite reinforcement on slope stability have been studied. The results obtained and the observations made clearly revealed that the addition of small amount of recycled aggregate not only increased the resisting forces of cement composites but also significantly improved the stability of reinforced soil. It has been demonstrated that the conventional reinforcement made of single material provided limited shear resistance and the shear performances of soil-structure interaction were enhanced by using the composite reinforcements. Among the six categories of composites tested in this study, the brick treated cement composites appeared to be more effective than the individual ones and the others. This 
study further suggests that the simple soil-structure interaction tests can effectively be used in characterization of shear behaviour of the surface treated mesh-reinforced cement composites.

\section{Acknowledgements}

The present study is partly supported by the Research Grant No. 22580271 with funds from Grants-in-Aid for Scientific Research, Japan. The writers gratefully acknowledge these supports. Any opinions, findings, and conclusions expressed in this paper are those of the authors and do not necessarily reflect the views of the sponsor.

\section{REFERENCES}

[1] M. Z. Hossain and M. Z. Islam, "Embankments Failure in Bangladesh: Causes and Recommendations," Indian Journal of Power and River Valley Development, Vol. 60, No. 10, 2010, pp. 166-171.

[2] M. Z. Hossain, "A Study on Thin Cementitious Composite (TCC) Materials for Soil Reinforcement Applications," Australian Journal of Agricultural Engineering, Vol. 1, No. 4, 2010, pp. 153-159.

[3] M. T. Islam, M. Z. Hossain and M. Ishida, "Analyses of Cost Comparison of Slope Protection Method between Japan and Bangladesh," International Journal of Environment, Vol. 2, No. 1, 2012, pp. 73-79.

[4] M. T. Islam, M. Z. Hossain and M. Ishida, "Designing Vertical and Horizontal Frame Structure for Slope Protection," Australian Journal of Agricultural Engineering, Vol. 3, No. 2, 2012, pp. 70-74.

[5] M. B. Hossain, T. Sakai and M. Z. Hossain, "River Embankment and Bank Failure: A Study on Geotechnical Characteristics and Stability Analysis," American Journal of Environmental Sciences, Vol. 7, No. 2, 2011, pp. 102107. doi:10.3844/ajessp.2011.102.107

[6] M. Z. Hossain, K. Ito, T. Sakai and M. B. Hossain, "Simplified Slope Stability Analysis for Earth Fill Structure with Various Types of Reinforcements," GEOSYNTHETICS ASIA 2012, 5th Asian Regional Conference on Geosynthetics, Bangkok, 13-16 December 2012, pp. 617623.

[7] J. M. Duncan, "State of the Art: Limit Equilibrium and Finite-Element Analysis of Slopes," Journal of Geotechnical Engineering, ASCE, Vol. 122, No. 7, 1996, pp. 577596. doi:10.1061/(ASCE)0733-9410(1996)122:7(577)

[8] D. G. Fredlund and J. Krahn, "Comparison of Slope Stability Methods of Analysis," Canadian Geotechnical Journal, Vol. 14, No. 3, 1977, pp. 429-439. doi:10.1139/t77-045

[9] M. Z. Hossain, "A Comparative Study on Pullout Behavior of Reinforcements for Effective Design of Reinforced Soil Structures," International Agricultural Engineering Journal, Vol. 16, No. 3, 2007, pp. 123-138.

[10] M. Z. Hossain, "A Potential Composite Material for Pos- sible Applications in Earth Reinforcement," Agricultural Engineering International, CIGRE Journal, Vol. 10, No. 36, 2008, pp. 1-18.

[11] M. Z. Hossain, "Pullout Response of Cement Composite Members Embedded in Soil," ACI Materials Journal, Vol. 105, No. 1, 2008, pp. 16-124.

[12] M. Z. Hossain and S. Inoue, "Determinate Method for Slope Stability Analysis of Earthen Structures," International Agricultural Engineering Journal, Vol. 16, No. 1, 2007, pp. $15-24$.

[13] M. Z. Hossain and T. Sakai, "A Study on Pullout Behavior of Reinforcement Due to Variation of Water Content of Soil," Agricultural Engineering International, CIGRE Journal, Vol. 9, No. 89, 2007, pp. 1-15.

[14] N. Janbu, "Slope Stability Computation," In: R. C. Hirschfeld and S. J. Poulos, Eds., Embankment-Dam Engineering, Casagrande, Krieger Publishing Company, Florida, 1987, pp. 47-86.

[15] N. R. Morgenstern and V. E. Price, "The Analysis of the Stability of General Slip Surface," Geotechnique, Vol. 15, No. 1, 1965, pp. 79-93. doi:10.1680/geot.1965.15.1.79

[16] E. Spencer, "A Method of Analysis of the Stability of Embankments Assuming Parallel Inter-Slice Forces," Geotechnique, Vol. 17, No. 1, 1967, pp. 11-26. doi:10.1680/geot.1967.17.1.11

[17] S. G. Wright and J. M. Duncan, "Limit Equilibrium Stability Analyses for Reinforced Slopes," TRB Paper No. 910441, Transportation Research Board, Washington DC, 1991.

[18] S. G. Wright, F. G. Kulhawy and J. M. Duncan, "Accuracy of Equilibrium Slope Stability Analysis," Journal of Soil Mechanics and Foundations Division, ASCE, Vol. 99, No. 10, 1973, pp. 783-791.

[19] M. Z. Hossain, "Development of a Small-Scale Universal Apparatus for Evaluating Soil-Structure Interaction," Journal of Civil Engineering and Architecture, Vol. 5, No. 4, 2011, pp. 314-321.

[20] K. Ito, M. Z. Hossain and T. Sakai, "Development of Design Charts for Reinforced Embankment Using Excel Spreadsheet Slope Stability Analysis," Proceedings of the 1st International Conferenec on Geotechnique, Construction Materials and Environment, Mie, 21-23 November 2011, pp. 183-186.

[21] M. Z. Hossain and H. Inagaki, "Dilatancy Behavior of Soil-Structure Interfaces for Farm Roads and Embankments," Australian Journal of Agricultural Engineering, Southern Cross Publisher, Vol. 2, No. 1, 2011, pp. 12-17.

[22] M. B. Hossain, M. Z. Hossain and T. Sakai, "Interaction Properties of Geosynthetic with Different Backfill Soils," International Journal of Geosciences, Vol. 3, No. 5, 2012, pp. 1033-1039. doi:10.4236/ijg.2012.35104

[23] M. B. Hossain, M. Z. Hossain and T. Sakai, "Evaluation of Sand/Geosynthetic Interface Behavior for Earth Reinforcement," International Journal of Geotechnical Engineering, Vol. 7, No. 3, 2013, pp. 452-465. 